\title{
NOTE
}

\section{CIVIL PROCEDURE: SECTION 0343(3) JURISDICTION AND THE PROPERTY- PERSONAL RIGHT DISTINCTION}

In Eisen v. Eastman, Judge Henry J. Friendly attempted to clarify some of the recurring problems surrounding the interpretation of section 1343(3) of title 28 , which provides the district courts with original jurisdiction for any civil action authorized by law to be commenced by any person:

To redress the deprivation, under color of any State law, statute, ordinance, regulation, custom or usage, of any right, privilege, or immunity secured by the Constitution of the United States or by any Act of Congress providing for equal rights of citizens or of all persons within the jurisdiction of the United States.

Section 1343(3) originated in the Civil Rights Act of $1871^{3}$ as the jurisdictional implementation of section 1983, which created a cause of action to redress the deprivation, under color of state law, of any rights, privileges, or immunities secured by the Constitution. ${ }^{4}$ Since the original jurisdiction of the district courts may be invoked under section 1343(3) without a meeting of the $\$ 10,000$ jurisdictional

1. 421 F.2d 560 (2d Cir. 1969).

2. 28 .U.S.C. $\S 1343(3)$ (1964).

3. Act of April 20, 1871, ch. 22, § 1, 17 Stat. 13.

4. This substantive provision was originally found in section 1 of the Civil Rights Act of April 20, 1871, 17 Stat. 13, as was its jurisdictional counterpart, the present 28 U.S.C. $\S 1343$ (3). The substantive provision, now codified as 42 U.S.C. $\S 1983$ (1964), provides:

Every person who, under color of any statute, ordinance, regulation, custom, or usage of any State or Territory, subjects, or causes to be subjected any citizen of the United States or other person within the jurisdiction thereof to the deprivation of any rights, privileges, or immunities secured by the Constitution and laws, shall be liable to the party injured in an action at law, suit in equity, or other proper proceeding for redress.

The phrase "and laws" was added in the Revised Statutes of 1875, REv. STAT. § 1979 (1875), which attempted to codify the existing law. There is no apparent explanation for the addition of this phrase to the original provision which referred only to "rights, privileges or immunities secured by the Constitution . ..."See Comment, The Civil Rights Acts and Mr. Monroe, 49 Calif. L. Rev. 145, 149 (1961); 16 Geo. Wash. L. Rev. 260, 262 (1948). For a discussion oi the problem of interpretation engendered by the difference in language between section 1983 ("and laws") and section 1343(3) ("any Act of Congress providing for equal rights") see notes 69-70 infra and accompanying text. 
amount required under the general "federal question" provision," the scope of section 1343(3) is frequently in controversy. In Eisen Judge Friendly reluctantly ${ }^{6}$ continued the Second Circuit's utilization of Mr. Justice Stone's test from Hague v. CIO that the jurisdictional amount requirement could be avoided "whenever the right or immunity is one of personal liberty, not dependent for its existence upon the infringement of property rights. . .."8

The plaintiff in Eisen brought an action in the district court under sections 1983 and 1343(3), alleging that a New York City Rent and Rehabilitation Director violated Eisen's constitutional right not to be deprived of property without due process of law by reducing the rents that he could charge under the City's rent control law. The district court, although finding that the action could not be sustained under section 1983 because the Civil Rights Act was not intended to apply to suits against municipalities, sustained jurisdiction under section 133I since Eisen's losses from the rent deductions would possibly exceed the $\$ 10,000$ jurisdictional amount within three years.?

On appeal, Judge Friendly quickly disposed of the district court's conclusion that Monroe v. Pape $e^{10}$ barred this suit by pointing out that the action was not against New York City but against Director Eastman and that an action against a state official acting under color of law is what section 1983 is "mainly about."11 Although the action was not barred as a suit against a municipality, it did not necessarily follow that the action was within the scope of section 1343(3). Noting that the Supreme Court had not thoroughly discussed this section since Hague v. $\mathrm{CIO}^{12}$ was decided in 1939,

5. 28 U.S.C. \$ 1331(a) (1964) provides: "The district courts shall have original jurisdiction of all civil actions wherein the matter in controversy exceeds the sum or value of $\$ 10,000$ exclusive of interest and costs, and arises under the Constitution, laws, or treaties of thc United States."

6. Although the Second Circuit had not squarely faced the issue, 421 F.2d at 565, Judge Friendly, "with a good deal less than complete assurance," held that "Justice Stone's Hague formulation generously construed, should continue to be the law of the circuit." Id. at 566. See Russo v. Shapiro, 309 F. Supp. 385, 390 (D. Conn. 1969).

7. 307 U.S. 496 (1939).

8. Id. at 531 .

9. The district court decision is unreported.

10. Monroe v. Pape, 365 U.S. 167 (1961). The Court in Monroe, after extensively examining the legislative history of section 1983, held that Congress had intended that no municipal liability should attach under section 1983.

11. 421 F.2d at 563 .

12. 307 U.S. 496 (1939). 
Judge Friendly reconsidered some of the problems then confronting the Court in attempting to define the scope of this jurisdictional grant.

\section{The Hague Decision}

The plaintiffs in Hague, individuals and unincorporated labor organizations, brought suit in a federal district court to enjoin various city officials from enforcing ordinances which allegedly violated the plaintiffs' constitutional rights of free speech and peaceable assembly. The plaintiffs contended, inter alia, that a city had wrongfully denied them a permit to assemble by invoking an ordinance prohibiting the leasing of any hall for a public meeting at which the overthrow of the government would be advocated. The plaintiffs, without conceding the validity of the ordinance, maintained that the purpose of their meeting was not to advocate the overthrow of the government but to explain the purposes of the National Labor Relations Act. The district court found jurisdiction under what are presently sections $1331,1343(1)$, and $1343(3),{ }^{13}$ and the court of appeals affirmed as to sections 1331 and $1343(3) \cdot{ }^{14}$ On certiorari, the Supreme Court held that jurisdiction could not be founded upon section 1331 because the record was bare of any valuation of the asserted rights. ${ }^{15}$ But in separate opinions by Justices Roberts and Stone, a majority of the court affirmed jurisdiction under the present section 1343(3).

Justice Roberts phrased the question as whether "freedom to disseminate information concerning the provisions of the National Labor Relations Act . . . is a privilege or immunity of a citizen of the United States secured against state abridgement by $\S 1$ of the fourteenth amendment, and whether ... [sections 1983 and 1343] afford redress in a federal court for such abridgement." ${ }^{16} \mathrm{He}$ concluded that the right to discuss federal legislation was an attribute of national citizenship secured by the privileges and immunities clause of the fourteenth amendment and that section 1343(3) provided jurisdiction over the deprivation of such a right. ${ }^{17}$

Justice Stone emphatically rejected Justice Roberts' attempt to

\footnotetext{
13. 25 F. Supp. 127 (D.N.J. 1938).

14. 101 F.2d 774, 787-90 (3d Cir. 1939).

15. 307 U.S. at 507-08.

16. 307 U.S. at 512 .

17. Id. at 513 .
} 
add new vitality to the privileges and immunities clause and felt the effort unnecessary and unwise, since Stone found that freedom of speech and assembly are rights secured to all persons, regardless of citizenship, by the due process clause of the fourteenth amendment..$^{18}$ Although he acknowledged that the right to assemble and discuss the National Labor Relations Act might be secured by the privileges and immunities clause to citizens of the United States, ${ }^{19}$ there was no allegation or finding that any of the plaintiffs were United States citizens. Stone noted that if the decision was to rest on the privileges and immunities clause, the decree was too broad since the plaintiffs should be protected, under that theory, in disseminating information concerning national legislation only, and the decree should guarantee only the rights of United States citizens, not all persons. Preferring "to avoid the unnecessary creation of novel constitutional doctrines," ${ }^{20}$ he believed that section 1983, in creating a cause of action to redress the deprivation by state action of the rights secured by the Constitution, allowed maintenance of the plaintiff's suit since freedom of speech and assembly are rights secured to persons by the due process clause of the fourteenth amendment. ${ }^{21}$ Seetion 1 of the Civil Rights Act of 1871 , the predecessor of section 1983, had directed that suits for violation of that Act be prosecuted in the district and circuit courts and did not require a jurisdictional amount. ${ }^{2}$ Congress in 1875 extended the jurisdiction of the circuit courts to suits "arising under the Constitution or laws of the United States" in which the amount in controversy exceeded $\$ 500 .{ }^{23}$ This statute requiring a jurisdictional amount has since coexisted with the

\section{Id. at 519 .}

19. Id. at 522 .

20. Id. at 525 .

21. Id. at $525-26$.

22. Act of April 20, 1871, ch. 22, § 1, 17 Stat. 13. Both the district and circuit courts had jurisdiction of suits arising under section 1 of the 1871 Act. The Revised Statutes of 1875 separated the district and circuit court jurisdiction. Section 563(12) provided jurisdiction for district courts while section 629(16) gave the circuit courts jurisdiction. In the revision of the Judicial Code in 1911, the two provisions were merged with original jurisdiction retained only in the district courts. Act of March 3, 1911, ch. 231, 36 Stat. 1087. See Note, Federal Judlclal Review of State Welfare Practices, 67 Colum. L. Rev. 84, 112-13 (1967). See note 70 infra and accompanying text for the problem posed by the difference in language betwcen sections 563(12) and 629(16) of the Revised Statutes of 1875.

23. Act of March 3, 1875, ch. 137, 18 Stat. 470. The Act of March 3, 1911, ch. 231, 36 Stat. 1087, abolished the circuit courts and transferred their jurisdiction to the district courts. The general "federal question" jurisdiction is now codified as 28 U.S.C. $\S 1331$ (1964). Sce note 5 supra and accompanying text. 
present section 1343(3), which confers jurisdiction of suits authorized by section 1 of the Civil Rights Act of 1871 and its successor, section 1983. Justice Stone considered it necessary to attempt a reconciliation of the two provisions since all suits authorized by section 1983 were, by definition, suits "arising under the Constitution or laws of the United States."

Stone was certain that Congress in 1875 had not intended to withhold jurisdiction from the federal courts of suits which Congress had authorized by the Civil Rights Act just four years earlier. Furthermore, he reasoned that the continuance of both statutes in the Judicial Code evidenced a congressional intention that suits could be brought under section 1343(3) after, as well as before, the 1875 Act. The fact that the 1911 amendment to section 24(1) of the Judicial Code, now section 1331, provided that this jurisdictional amount requirement should not be construed as applicable to section 1343(3) cases $^{24}$ strengthened Stone's conclusion. He reasoned that the two jurisdictional provisions could be harmonized only by treating section 1343(3) as conferring federal jurisdiction for suits brought under section 1983 when the "right asserted is inherently incapable of pecuniary valuation."25 Examining the only two cases where the court had been confronted with the task of construing section $1343(3),{ }^{26}$ Stone concluded that

whenever the right or immunity is one of personal liberty, not dependent for its existence upon the infringement of property rights, there is jurisdiction in the district court under section 24(14) of the Judicial Code [section 1343(3)] to entertain it without proof that the amount in controversy exceeds [the requisite amount].7

Judge Friendly, although acknowledging that Stone's test "has

24. Act of March 3, 1911, ch. 231, 36 Stat. 1087, 1091, amended $\S 24(1)$ of the Judicial Code to dircct: "[T] he foregoing provision as to the sum of value of the matter in controvcrsy shall not be construed to apply to any of the succeeding paragraphs of this section." The amendment also increased the jurisdictional amount to $\$ 3,000$.

25. 307 U.S. at 530 .

26. The two cases were Holt v. Indiana Mfg. Co., 176 U.S. 68 (1900) and Truax v. Raich, 239 U.S. 33 (1915). In Holt the plaintiff sought to restrain the state from taxing his patent rights, alleging that he was exempt from taxation by virtue of federal patent law. Unable to meet the jurisdictional amount, he brought his claim under section 1343(3). The Supreme Court remarked: "Assuming they [sections 1343(3) and 1983] are still in force, it is sufficient to say that they refer to civil rights only and are inapplicable here." Id. at 72 . The court made no attempt to define "civil rights." For a discussion of Truax see notes 42 \& 43 infra and accompanying text.

27. 307 U.S. at 531-32. 
been considerably easier to state than to apply,"28 nevertheless felt that there is "something essentially right about it, especially if one accepts, as we do, his premise that the overlap between 28 U.S.C. $\S 1331$ and 28 U.S.C. $\S 1343(3)$ should be explained in some rational way." ${ }^{29}$ Friendly believed that the Stone formulation, while preserving jurisdiction in the type of case Congress was concerned about in 1871 and in which later Congresses would have desired to be within the statute, had the merit of excluding cases that neither the 1871 Congress nor later Congresses contemplated..$^{30}$ Although concluding that Stone's formulation "generously construed" should be the law in the Second Circuit, Friendly found no jurisdiction for Eisen's complaint under section 1343(3) since it only alleged the loss of money.

\section{Property v. Personal Right: Is It Always That Clear?}

The first case construing section 1343(3) to reach the Supreme Court after Hague illustrated the problems inherent in Stone's formulation. In Douglas $v$. City of Jeannette ${ }^{32}$ the plaintiffs, Jehovah's Witnesses, brought suit under section 1343(3) to restrain the City of Jeannette from criminally prosecuting them for violating a city ordinance prohibiting the solicitation of merchandise orders without first procuring a license. Although refusing to grant equitable relief, Justice Stone, writing for the majority, agreed that the district court had jurisdiction since the Witnesses' contention that the ordinance deprived them of the right of free speech stated a cause of action under section 1983. At first glance, Douglas seemis to fit snugly into Justice Stone's personal-property right distinction, ${ }^{33}$ but closer examination raises questions. It appears from the record that the city was willing to allow the Witnesses to distribute their literature free, but since their primary purpose was to sell the material, the Witnesses responded that this would be contrary to their method of "doing business." Indeed, the City was

28. 421 .F.2d at 564 .

29. Id. at 565 .

30. Id. at $565-66$.

31. Id. at 566. American Commuters Ass'n. v. Levitt, 405 F.2d 1148, 1151 n.4 (2d Cir. 1969), decided earlier in 1969, had specifically avoided the question of whether section 1343(3) could apply to "property rights."

32. 319 U.S. 157 (1943).

33. Judge Friendly lists Douglas as one of the cases clearly involving a right of personal libcrty. 421 F.2d at 564.

34. 319 U.S. at 168 (Jackson, J., concurring). 
prosecuting under an ordinance prohibiting the solicitation of orders for merchandise, which would indicate that the right infringed was a property right, that is, the right to distribute literature for sale. ${ }^{35}$ In addition to the property-personal right questions it raises, Douglas brings into focus the importance of the proper formulation of the Stone test. If the test for section 1343(3) jurisdiction is whether the right infringed is "inherently incapable of pecuniary valuation,"36 instead of the property-personal right distinction, were not the rights which the Witnesses' claimcd to be infringed capable of pecuniary valuation? Although freedom of expression is clearly a personal right rather than proprietary right, the Witnesses could have "purchased" this right from the City by paying the license fee. ${ }^{37}$ In other words, if personal rights can be valued, should section 1343(3) jurisdiction be precluded?'38

In 1947, the Sixth Circuit in Glicker v. Michigan Liquor Control Commission $^{39}$ sustained section 1343(3) jurisdiction when the plaintiff sought an injunction to regain a liquor license which she alleged had been revoked by state officials purposefully discriminating against her. There was no discussion of Stone's property-personal right distinction, although revocation of a liquor

35. Compare Douglas with Adams v. City of Park Ridge, 293 F.2d 585 (7th Cir. 1961). In $A d a m s$ a charitable association alleged that the city ordinance requiring city council permission to solicit and collect funds was unconstitutional. The court upheld jurisdiction under section 1343 (3) on the theory that the right to disseminate information about charitable organizations is a right of free speech, thus a "personal right." The court seems not to have considered that the purpose of plaintiff's suit was to enable plaintiff to solicil funds, arguably a "property right." It is interesting to note that in Joe Louis Milk Co. v. Hershey, 243 F. Supp. 351 (N.D. 111. 1965), Adams was cited for the proposition that section 1343(3) confers jurisdiction for suits alleging only the deprivation of personal rights. Id. at 354 . See note 36 infra and accompanying text.

36. Many commentators and judges simply express Stone's test as conferring section 1343 (3) jurisdiction whenever the right is "inherently incapable of pecuniary valuation," and others use this phrase interchangeably with the property-personal right distinction. See, e.g., Bussie v. Long, 383 F.2d 766, 769 (5th Cir. 1967); C. Wright, Federal Courts 109-10 (1970). Judge Friendly, perhaps recognizing the problem which could be engendered, stated that he thought Stone's formulation was to be found in the phrase "whenever the right or immunity is one of personal liberty, not dependent for its existence upon the infringement of property rights" rather than the phrase "incapable of valuation," $421 \mathrm{~F} .2 \mathrm{~d}$ at $564 \mathrm{n} .7$.

37. Cf. Healy v. Ratta, 292 U.S, 263 (1934). There a merchant claimed that a state-wide license tax violated his right to equal protection of the laws. The Court held that the amount in controversy for purposes of meeting the jurisdictional requirement was the amount of the disputed tax.

38. See D. Currie, Federal Courts, Cases and Materials 428 (1968); H. M. Hart \& H. Wechsler, The Federal Courts AND the Federal System 841 (1953).

39. 160 F.2d 96, 97 (6th Cir. 1947). 
license would appear to be a loss of a property right. Unless the case is viewed as holding that the plaintiff was deprived of her right to engage in the business of her choice, which could perhaps be characterized as a personal right, the court appears to have ignored Stone's distinction..$^{40}$ Glicker was the first of a long line of liquorlicense cases in which federal courts assumed jurisdiction under section $1343(3)$ to redress the deprivation of what are at least colorably. "property rights." 41

The difficulty in distinguishing between proprietary and personal interests is perhaps nowhere better illustrated than in cases in which employment discrimination is alleged to have deprived a person of his job or livelihood in violation of the equal protection clause. Truax $v$. Raich, ${ }^{42}$ the first such case brought under section 1343(3), was cited by Stone to support his property-personal right distinction. Raich, an alien, sought to have an Arizona statute which required that certain employers hire not less than 80 percent native-born citizens declared unconstitutional. Threatened with discharge from his job in order that his employer might comply with the statute, Raich sought a restraining order, claiming that the statute deprived him of equal protection of the law. The Supreme Court upheld jurisdiction and stated that the right to work for a living "is the very essence of ... personal freedom." 43 Cases involving alleged interference with employment rights or opportunities have generally followed Truax and upheld jurisdiction under section 1343(3). For instance, in Burt v. City of New York, ${ }^{44}$ an architect, claiming that his applications for building permits were denied by city officials because he was the victim of purposeful discrimination, successfully obtained 1343(3) jurisdiction. And the First Circuit has similarly upheld jurisdiction when school teachers alleged that municipal

40. See Note, The Proper Scope of the Civil Rights Acts, 66 HARv. L. REv. 1285, 1289 (1953). Compare the cases involving employment discrimination cited at notes $42-46$ infra.

41. Berry v. Allen, 411 F.2d 1142 (6th Cir. 1969); Atlanta Bowling Center, Inc. v. Allen, 389 F.2d 713 (5th Cir. 1968); Hornsby v. Allen, 326 F.2d 605 (5th Cir. 1964).

42. 239 U.S. 33 (1915).

43. 239 U.S. at 41. See Crane v. Johnson, 242 U.S. 339 (1917). Justice Stone, in citing Trawx and Crane to support his distinction, stated: "[1]n both [cases] the gist of the cause of action was not damage or injury to property, but unconstitutional infringement of a right of personal liberty not susceptible of valuation in money." 307 U.S. at 531 .

44. 156 F.2d 791 (2d Cir. 1946). See Birnbaum v. Trussel, 371 F.2d 672 (2d Cir. 1966) (section 1343(3) jurisdiction allowed when the plaintiff, a public employec, alleged that he was removed from his job on arbitrary grounds). Comment, The Civii Rights Act, Emergence of an Adequate Federal Civii Remedy? 26 1ND. L.J. 361, 367-68 (1951). 
officials were impairing contractual obligations in violation of the Constitution by preventing the allocation of sufficient funds to pay teacher salaries. ${ }^{45}$ No doubt the right to earn a living can be classified a "personal right" if one considers such concomitant factors as the right to live where one pleases and to pursue the work one enjoys, but arguably the loss of employment is primarily the loss of wages, an item traditionally considered a proprietary interest.

Cases such as Glicker, Truax, and Burt, which seemingly involve deprivation of proprietary interests, can probably be explained in another way. When a person alleges that he is being deprived of a liquor license or employment because of purposeful discrimination in violation of the equal protection clause, his right to be treated equally has been infringed ${ }^{46} \mathrm{He}$ is complaining not only of the interest infringed-whether personal or proprietary-but of the fact that he is being treated unequally. In other words, the right to equality exists apart from the interest infringed, and the right to equality is a personal right. ${ }^{47}$ It has thus been argued that sections 1343(3) and 1983 play an important function in equal protection cases by providing a federal remedy for the deprivation of personal rights which might otherwise be without means of redress. ${ }^{48}$

\section{Recent Section 1343(3) Litigation}

The Fifth Circuit, which has largely ignored Stone's formulation without openly repudiating it, has generated substantial confusion concerning section 1343(3). In Hornsby v. Allen, ${ }^{49}$ Barnes v.

45. Cobb v. City of Malden, 202 F.2d 701 (1st Cir. 1953).

46. Justice Stone did not make an exception to his property-personal right distinction in cases alleging a denial of equal protection. See $66 \mathrm{HARV}$. L. Rev., supra note 40 at 1290. For cases where the equal protection clause was unsuccessfully relied on to proteet property interests in a section 1343(3) suit, see 26 IND. L.J., supra note 44, at 367 n.33. For a case where the court upheld section 1343(3) jurisdiction under the equal protection clause for a claim involving only a property right, sce Powell v. Workmens Compensation Bd., 327 F.2d 131 (2d Cir. 1964).

47. Compare this to a denial of due process where the plaintiff alleges infringement of an independent interest, such as a property interest or right to be free from illegal search. 49 CALIF. L. Rev., supra note 4, at 162. In alleging a denial of due process, the plaintiff claims a deprivation of the substantive interest infringed, but in alleging a denial of equal protection the plaintiff is claiming a deprivation not only of the substantive interest infringed but also the deprivation of the right to be treated equally. Id.

48. Id. at 163.

49. 326 F.2d 605 (5th Cir. 1964). In Hornsby and many other decisions, section 1343(3) is not discussed, with only section 1983 being mentioned. Although the construction and scope of the two statutes should be the same, see note 4 supra, recall that section 1983 is not 
Merritt,50 and Atlanta Bowling Center, Inc. v. Allen,, 1343(3) jurisdiction was upheld to insure nondiscriminatory treatment in the granting of liquor licenses by the state. Jurisdiction was similarly granted when the plaintiff in Mansell $v$. Saunders $s^{52}$ alleged that his rights under the due process and equal protection clauses were violated because he was denied a garbage collection franchise, while in McGuire $v$. Sadler, ${ }^{53}$ the plaintiff claimed impairment of contract obligations in violation of his constitutional rights when his land was wrongfully sold by the state land commissioner. In none of the above cases can it be said that the right allegedly infringed was anything other than a "property right" in the traditional sense..$^{54}$

Bussie v. Long, ${ }^{55}$ which seemed to mark the Fifth Circuit's retreat from its neglect of Stone's formulation, can probably be explained in another way. Bussie was a class action brought by two Louisiana taxpayers to compel members of the Louisiana Tax Commission to discharge their duty under the Louisiana constitution and statutes to establish the actual cash value for ad valorem tax assessments and to equalize assessments. The court, relying on Stone's property-personal right distinction, held that there was no federal jurisdiction under section 1343(3) since only a property or monetary right was involved. ${ }^{56}$ Noting that Hornsby, Mansell, and McGuire involved only "property rights," the court acknowledged "[t]here is admittedly a fine line of distinction between these cases and the instant case,", but added that these holdings could not be extended to cases involving tax assessments. "Tax assessment" cases may justifiably be excluded from section 1343 (3) jurisdiction even if the property-personal right distinction is not followed in other areas.

jurisdictional but only creates a cause of action. 49 CALIF. L. REV., supra note 4, at 148. See Dyer v. Kazuhisa Abe, 138 F. Supp. 220 (D. Hawaii 1956), rev'd, 256 F.2d 728 (9th Cir. 1958) (discussion of the difference between sections $1343(3)$ and 1983).

50. 376 F.2d 8 (5th Cir. 1967).

51. 389 F.2d 713 (5th Cir. 1968).

52. 372 F.2d 573 (5th Cir. 1967).

53. 337 F.2d 902 (5th Cir. 1964) (alternate holding). See Blume v. City of Deland, 358 F.2d 698 (5th Cir. 1966) (section 1343(3) jurisdiction upheld when a property owner claimed appropriation of property without due process). Cf. Ream v. Handley, 359 F.2d 728 (7th Cir. 1966).

54. It may be contended, however, that by an expansive rcading of the "equality theory," see note 62 infra and accompanying text, these rights are personal rights.

55. 383 E.2d 766 (5th Cir. 1967).

56. 383 F.2d at 769.

57. Id. 
As most courts entertaining such cases have recognized ${ }^{58}$ Congress has expressed its desire that state courts are the proper forums to adjudicate claims based on state tax statutes when a plain, speedy, and efficient remedy is made available to the complainant in the courts of such state. ${ }^{59}$ In Abernathy $v$. Carpenter, ${ }^{60}$ the Supreme Court affirmed the district court's decision that section 1343(3) did not confer jurisdiction over a claim by a nonresident taxpayer to be exempted from certain state income taxes. But, instead of reaffirming the vitality of Stone's property-personal right formulation, these tax cases should be recognized as a special class of case which Congress has expressly left to the state courts whenever an adequate remedy is available.

In contrast to the Fifth Circuit, which prefers to ignore Justice Stone's formulation without expressly criticizing it, at least two courts has squarely faced the issue. In a recent California district court case, the plaintiff alleged that tests given to applicants for position with the Oakland Police Department were discriminatory in nature. ${ }^{61}$ The court was generally critical of Stone's formulation, and stated that if it were faced with the problem as a matter of first impression it would reject a strict "property-personal liberty" test ${ }_{2}^{62}$ but concluded that even if the distinction were accepted, the plaintiff's claim would have established 1343(3) jurisdiction since employment is far more precious than a "mere property" right. ${ }^{63}$ The District Court for the Northern District of Illinois has held that section 1343(3) conferred jurisdiction for a complaint that the Illinois Director of Insurance had deprived the plaintiff of property without due process of law. ${ }^{64}$ The Director was attempting to levy

58. See, e.g., Gray v. Morgan, 371 F.2d 172 (7th Cir. 1966), cert. denied, 386 U.S. 1033 (1967); Alterman Transp. Lines, Inc. v. Public Serv. Comm'n., 259 F. Supp. 486 (M.D. Tenn. 1966), affd per curiam, 386 U.S. 262 (1967); Olan Mills, Inc. v. City of Opelika, 207 F. Supp. 332 (M.D. Ala. 1962); Reiling v. Lacey, 93 F. Supp. 462 (D. Md. 1950), appeal dismissed, 341 U.S. 901 (1951). Hornbeak v. Hamm, 283 F. Supp. 549 (M.D. Ala.), affd, 393 U.S. 9 (1968), another tax case, contains a good discussion of Bussie and the Fifth Circuit's attempt to reconcile it with Hornsby, Mansell, and $M c$ Guire.

59. 28 U.S.C. $\S 1341$ (1964) provides: "The district courts shall not enjoin, suspend or restrain the assessment, levy or collection of any tax under State law where a plain, speedy and efficient remedy may be had in the courts of such State."

60. Abernathy v. Carpenter, 208 F. Supp. 793 (W.D. Mo. 1962), aff d per curiam, 373 U.S. 241 (1963).

61. Penn v. Stumpf, 308 F. Supp. 1238 (N.D. Cal. 1970).

62. Id. at 1245 .

63. Id. at $1245-46$.

64. Joe Louis Milk Co. v. Hershey, 243 F. Supp. 351 (N.D. 1ll. 1965). See also Detroit Edison Co. v. East China School Dist., 378 F.2d 225 (6th Cir.), cert. denied, 389 U.S. 932 
on the plaintiff for money allegedly owed to a defunct insurance company which had issued contingent liability insurance policies regardless of whether or not the "member" had consented or actually received any protection. The court stated that the language of section 1343(3) expressed no distinction between the constitutional protection afforded property rights and human rights and that there was no logic or policy with which to make property rights less deserving of protection. ${ }^{65}$ In rejecting the notion that it should abstain because only property rights were involved, the court observed that "to individuals of limited financial means, deprivation of property can have as serious an effect as an infringement upon personal liberty." ${ }^{\prime 6}$

\section{The Welfare Cases}

The continuing validity of Stone's property-personal right distinction becomes questionable when viewed with regard to federal court jurisdiction over welfare cases. Although Judge Friendly expressed concern that adherence to Stone's formula might have the disadvantage of barring welfare recipients from federal forums, apparently such is not the case. Although at first glance welfare payments would appear to be a "property right," most federal courts have found jurisdiction under section 1343(3) when welfare claimants have alleged either infringement of eonstitutional rights or the application of state laws or regulations inconsistent with the provisions of the Social Security Act ${ }^{68}$ Because of the difference in language between sections 1983 and $1343(3){ }^{69}$ whether the statutory claims could be brought under the latter has been questioned since

(1967); Progress Dev. Corp. v. Mitchell, 286 F.2d 222 (7th Cir. 1961). These two cases involve pure "property rights" which intimate a "latitudinarian view" with respect to Justice Stone's distinction.

65. 243 F. Supp. at 354.

66. Id. at 357 .

67. 421 F.2d at 566 n.10. Most welfare claims cannot be brought under section 1331 since the amount in controversy would not exceed $\$ 10,000$, and it is unlikely that plaintiffs in a class action would be allowed to aggregate their claims. See 67 CoLUM. L. REv., supra note 22 , at 111 .

68. See, e.g., King v. Smith, 392 U.S. 309 (1968); Damico v. California, 389 U.S. 416 (1967); Kelly v. Wyman, 294 F. Supp. 893 (S.D.N.Y. 1968), aff d sub nom. Goldberg v. Kelly, 397 U.S. 254 (1970); Sweeny v. Pennsylvania Dep't of Public Assistance Bd., 33 F. Supp. 587 (M.D. Pa. 1940), aff d, 119 F.2d 1023 (3rd Cir.), cert. denied, 314 U.S. 611 (1941). But see, McCall v. Shapiro, 416 F.2d 246 (2d Cir. 1969).

69. See note 4 supra. 
the Social Security Act is not a law "providing for equal rights."70 But even if section 1343(3) is construed to confer jurisdiction over a statutory claim only when the plaintiff is seeking relief under a "law providing for equal rights," the welfare claimant will usually be unaffected. Any offensive state practices are almost always challenged on both constitutional and staturory grounds." Under the doctrine of pendent jurisdiction, the courts usually will have jurisdiction over the statutory claim, even if the constitutional claim fails on the merits ${ }^{72}$ and even if the statutory claim is not based upon a law providing for equal rights.

Apparently only the Second Circuit has raised the objection that welfare payments are "property rights" and thus outside the scope of sections 1343(3) and 1983..$^{73}$ Judge Friendly observed in Eisen that every case in which the Supreme Court had sustained jurisdiction under section 1343(3) could be encompassed in Stone's formulation with the possible exception of King $v$. Smith. ${ }^{74}$ In that case Alabama's "substitute father" regulation was invalidated because of

70. See 67 Colum. L. REV., supra note 22, at 112-14. Although section 1343(3) is now worded so as to limit jurisdiction to suits to redress deprivations secured by "any Act of Congrcss providing for cqual rights", the origin of this limitation is unclear. When the jurisdictional provisions of the Civil Rights Act of 1871 were codified in the Revised Statutes of 1875, sections 1979 (now section 1983) and 563(12), the provisions for civil rights jurisdiction in the district courts, were identical in scope and contained no language limiting the word "laws." But section 629(16), whieh provided circuit court jurisdiction over civil rights suits, contained the limiting phrase "laws providing for equal rights." In 1910, when the jurisdiction of the circuit courts was merged into that of the district courts with original jurisdiction remaining only in the district courts, the limiting phrase was retained. There is nothing to indicate that Congress intended to limit the jurisdiction of the district court by inserting the qualifying phrase from the circuit court provision. See S. REP. No. 388, 6Ist Cong., 2d Sess., pt. 1, at 15 (1910).

In Bomar v. Keyes, I62 F.2d 136 (2d Cir.), cert. denied, 332 U.S. 825 (1947), Judge Learned Hand held that a school teacher's claim that her "privilege" under federal läw was violated when she was fired for being absent for four days to serve on a federal jury stated a cause of action under section 1983. The federal statute creating the "privilege" to serve on a jury was certainly not a "law providing for equal rights." For other cases where district courts have assumed that section 1343(3) provides jurisdiction of suits to redress the deprivation of rights conferred by a federal statute, see 49 CALIF. L. REv. supra note 4, at 150 n.42. See also Note, Damage Suits Under Civil Rights Act for Deprivation of Federal Statutory Rights, 47 Colum. L. Rev. 1082 (1947); 66 HaRV. L. Rev., supra note 40, at 1291-93; 16 GEO. WASH. L. REV. 260 (I948); 26 TEX. L. Rev. 531 (I948).

71. 67 Colum. L. REv., supra note 22 , at I14.

72. See id., King v. Smith, 392 U.S. 309 (1968); McCall v. Shapiro, 416 F.2d 246, 251 (2d Cir. 1969) (concurring opinion).

73. See 416 F.2d at 250 . Note how the court repeatedly confuses sections 1343(3) and 1983 and speaks of section 1983 as being jurisdictional.

74. 392 U.S. 309 (1968). 
its inconsistency with the federal statute under which the Aid For Dependent Children program was administered. The Alabama regulation denied payments to the children of a mother who cohabited with an able-bodied man. Friendly rationalized that perhaps the denial of payment caused not merely economic loss, a property right, but also infringed the "liberty" of the children to grow up with financial aid or infringed Mrs. Smith's "liberty" to have Mr. Williams visit her on weekends. ${ }^{75}$ Relying on King $v$. Smith, a district court has found 1343(3) jurisdiction where the plaintiffs alleged a denial of equal protection in the dispensation of back-to-school clothing allowances. ${ }^{76}$ After discussing Judge Friendly's characterization of the rights infringed in King, the district judge concluded: "[I]s there not also a similar 'liberty' in this case to have clothing to wear to school?"77

These welfare cases seem to recognize that Stone's distinction is difficult to apply because the loss of property often has an effect on personal interests. ${ }^{78}$ Besides assuming that personal and proprietary interests are separable, Stone's formula has the effect of designating "personal interests" as more deserving of federal protection. But as Professor Reich has observed, civil liberties must have a basis in property:

[T]he Bill of Rights comes into play only at extraordinary moments of conflict or crisis, [but] property affords day-to-day protection in the ordinary affairs of life. Indeed, in the final analysis the Bill of Rights depends upon the existence of private property. Political rights presuppose that individuals and private groups have the will and the means to act independently. But so long as individuals are motivated largely by self-interest, their well-being must first be independent. ${ }^{79}$

Without the economic security which proprietary rights provide, one's personal liberty is surely less secure. ${ }^{80}$ This is demonstrated in the case of the welfare. recipient-or other poor person-where the loss of money or property affects one's right to be free from hunger,

75. $421 \cdot$ F.2d at 564.

76. Russo v. Shapiro, 309 F. Supp. 385 (D. Conn. 1969).

77, Id. at 391 .

78. See, e.g., id. at 392-93; Sweeny v. Pennsylvania Dep't of Pub. Assistance Bd., 33 F. Supp. 587 (M.D. Pa. 1940), aff d, 119 F.2d 1023 (3rd Cir.), cert. denied, 314 U.S. 611 (1941) (loss of welfare affects personal rights); 66 HARV. L. REV., supra note 40, at 1289.

79. Reich, The New Property, 73 Y ALE L.J. 733, 771 (1964).

80. See W. LippMan, The Method of Freedom 101 (1935); Reich, supra note 79, at 77174. 
to be fully clothed, or adequately housed. It would be incongrous to argue that the loss of the means to provide these necessities, albeit less than the $\$ 10,000$ value necessary for section 1331 jurisdiction, is any less valuable to some people than the loss of freedom of speech or the right to vote. ${ }^{81}$ This is not to place "property rights" above "personal rights" or vice versa but only to recognize that Stone's distinction ignores the inseparability of property rights and personal rights and fails to recognize that to many people the deprivation of a property right worth only $\$ 1,000$ is as important as the deprivation of a personal right "incapable of pecuniary valuation."

\section{What Did the Framers Intend?}

Since the basis for Stone's property-personal right distinction is not evident on the face of section 1343(3), is there anything in the legislative history of the 1871 Act or other post-Civil War legislation to indicate that Congress intended that property interests were not to be protected by sections 1983 and 1343(3)? Without attempting a detailed discussion of the voluminous legislative history of the period, it is perhaps important to point out that the framers of the fourteenth amendment and the 1871 Act from which both section 1983 and section 1343(3) were derived evidenced no intention to distinguish between the protection of proprietary or personal interests. ${ }^{82}$ Of course such a conclusion is not determinative of the scope of section 1343(3) since the problem of the coexistence of sections 1331 and $1343(3)^{83}$ and the intention of later Congresses still remains. Section 1 of 1871 Act provided a cause of action to any person who was deprived of "any rights, privileges, or immunities secured by the Constitution"\$4 under color of state law, and provided that "such proceeding [should] be prosecuted in the several district

81. The courts are now beginning to recognize the relationship between the loss of property and the right to life itself. See; e.g., Goldberg v. Kelly, 397 U.S. 254 (1970); Sniadach v. Family Finance Corp., 395 U.S. 337; 341-42 (1969); See also 1969 DUKE L.J. 1285, 1290-92.

82. This is not to say that the protection of property interest was emphasized in the debates to the exclusion of personal interests, or vice versa. The point is that there was no attempt to distinguish between the two.

83. See note 105 infra and accompanying text.

84. Act of April 20,187I, ch. 22, $\S 1,17$ Stat. 13. The title of the bill made its purpose abundantly clear: "An Act to enforce the Provisions of the Fourteenth Amendment to the Constitution of the United States, and for other Purposes." See notes 4 and 70 supra for a discussion of the addition of the phrase "and laws" in the Revised Statutes of 1875. 
and circuit courts of the United States . . .."85 The substantive provision, which became the present section 1983, was separated from the jurisdictional provision, which became the present section 1343 , in the 1875 revision ${ }^{86}$ The 1871 Act, popularly known as the $\mathrm{Ku}$ Klux Klan Act, was intended to provide a remedy for the deprivation of rights which had recently been secured by the fourteenth amendment. ${ }^{87}$ The "rights, privileges, or immunities" secured by the 1871 Act are the same "rights, privileges, or immunities" secured by the fourteenth amendment. ${ }^{88}$

In passing the Ku Klux Klan Act, Congress responded to reports of the lawless conditions existing in the South in 1871 and recognized the necessity of acting to protect person and property ${ }^{80}$ President Grant, on March 23, 1871, urged Congress to act:

A condition of affairs now exists in some States of the Union rendering life and property insecure . . . the proof that such a condition of affairs exists in some localities is now before the Senate .. . Therefore, 1 urgently recommend such legislation as in the judgment of Congress shall effectually secure life, liberty and property, and the enforcement of law in all parts of the United States. ${ }^{80}$

Thus, it appears Congress was aware that both life and property were being rendered insecure by the lawless conditions in the South and that legislation was needed to enforce the provisions of the fourteenth amendment. ${ }^{91}$

85. 17 Stat. 13 (1871). See note 23 supra for a discussion of the merger of circuit and district court jurisdiction and note 70 supra for a discussion of the problem of interpretation engendered by the discrepency in language between the district and circuit court provisions.

86. The common origin, combined with the fact of the almost identical phraseology of the two statutes, has led most commentators to conclude that the scope of the two provisions is coextensive. D. CURRIE, supra note 38, at 427 (1968); 49 CALIF. L. ReV., supra note 4, at 147; 67 Colum. L. Rev., supra note 22, at 111-12, Note, Limiting the Section 1983 Action in the Wake of Monroe v. Pape, 82 HARv. L. Rev., 1486, 1506 (1969); 66 HARV. L. REv., supra note 40 , at 1289.

Judge Friendly observes that even though the two provisions are subject to the same interpretation, it would lessen .the confusion surrounding section 1343(3) if its jurisdictional nature was kept in mind. $421 \mathrm{~F} .2 \mathrm{~d}$ at $565 \mathrm{n} .8$.

87. See note 84 supra and accompanying text. See Monroe v. Pape, 365 U.S. 167, 171 (1967).

88. Poole, Statutory Remedies for the Protection of Civil Rights, 32 One. L. Rev. 210, 222 (1953).

89. See S. ReP. No. 1, 42d Cong., Ist Sess. (1871); H.R. ReP. No. 22. $42 \mathrm{~d}$ Cong., $2 \mathrm{~d}$ Scss., pts. 1-13 (1871). For an extensive discussion of the remarks of legislators concerning the proposed legislation see 365 U.S. at 172-83.

90. CONG. Globe, 42d Cong., Ist Sess. 244 (1871) (emphasis added).

91. See Gressman, The Unhappy History of Civil Rights Legislation, 50 Micu. L. Rev. 1323, 1334 (1950). See note 89 supra and accompanying text. 
Congress did not define very clearly exactly what "rights, privileges, and immunities" it intended to protect by the enactment of the fourteenth amendment, but there is no indication that personal rights were emphasized over proprietary rights. Congressman Bingham, the principal architect of the amendment, wanted to secure the rights already protected by the Bill of Rights from federal infringement against state encroachment ${ }^{92}$ Throughout the debates there is nothing to indicate that Congress intended that the fourteenth amendment differentiate between personal and property rights. ${ }^{93}$

But there is one item of persuasive evidence that the framers of the fourteenth amendment intended to protect both property and personal rights. There is a general consensus that the amendment's first section was intended to incorporate the provisions of the Civil Rights Act of 1866 into the Constitution.94 The framers of the first Civil Rights Bill were not willing to chance a later Congress negating their work. Entitled "An Act to protect all Persons in the United States in their Civil Rights, and furnish the Means of their Vindication," the first Civil Rights Act certainly protected such property interests as the right to own land. ${ }^{95}$ And as the title indicates, these "property rights" being protected were considered "civil rights." The evidence before the Thirty-ninth Congress

92. J.B. JAMEs, The Framing of the Fourternth AMENDMeNT 105 (1956). Bingham stated that he had read Barron v. Baltimore, 32 U.S. (7 Pet.) 242 (1833), where Marshall had been forced to hold that the Bill of Rights imposed no limitations on the power of the states "and that is what induced me to attempt to impose by constitutional amendments new limitations on the power of the States . . . " CoNg. GlOBE, 42d Cong., 1st Sess. App. 83 (1871). It is worth noting that Barron v. Baltimore was a case concerning only a property right since the city had taken private property for public use without compensation. This at least intimates that Bingham intended property rights to be seeured by the fourteenth amendment.

93. But see Comment, Federal Courts-Jurisdiction Over Violations of Civil Liberties by State Governments and by Private Individuals, 39 MiCH. L. Rev. 284, 287 n.13 (1939).

94. J. tenBroek, The ANTISLAVEry Origins of the Fourteenth Amendment 183-85 (1951); H. FLACK, The ADOPTION OF THE FOURTEENTH AMENDMENT 20, 54, 96 (1908); J.B. JAMES, supra note 92, at 128-29; CONG. GloBE, 39 Cong., 1st Sess. 2511 (1866) (remarks of Rep. Eliot); CoNG. Globe, 39th Cong., 1st Sess. 2462 (1866) (remarks of Rep. Garfield).

95. Act of April 6, 1866, ch. 3I, § 1, 14 Stat. 27 provides:

That all persons born in the United States . . . are hereby declared to be citizens of the United States; and such citizens, of every race and color . . . shall have the same right, in every State and Territory in the United States, to make and enforce contracts. to sue, be parties, and give evidence, to inherit, purchase, lease, sell, hold, and convey real and personal property, and to full and equal benefits of all laws and proceedings for . . . person and property, as is enjoyed by white citizens . . . . (emphasis added). 
showed that Negroes were being deprived of their right to own property ${ }^{96}$ and Congress intended to remedy that situation.

Section 1 of the Act of 1871 was in large measure intended to carry out the principles embodied in the Civil Rights Act of 1866 , which had been incorporated into the fourteenth amendment, ${ }^{97}$ and neither the 1866 Act nor the fourteenth amendment intimated that property rights were to be protected from state infringement less vigorously than personal rights. The post-Civil War decisions of the Supreme Court recognized that the fourteenth amendment protected proprietary interests. ${ }^{98}$ For example, a case decided shortly after the passage of the 1871 Act upheld jurisdiction under section 1343(3) when a corporation alleged that the state was interfering with the corporation's property rights. ${ }^{99}$ When section 1 of the 1871 Act provided district courts with jurisdiction to redress the deprivation of "any right, privilege or immunity secured by the Constitution . . ." it probably intended exactly that..$^{100}$

The extensive discussion of the scope of section 1983 in Monroe v. Pape ${ }^{101}$ seems to support this interpretation. The Monroes claimed that the invasion of their homes by Chicago police, subsequent warrantless search, and arrest and detention of Mr. Monroe without warrant or prompt arraignment constituted a deprivation of their "rights, privileges, or immunities secured by the Constitution" within the meaning of section 1983. Justice Douglas stated that an "[a]llegation of facts constituting deprivation under color of state authority of a right guaranteed by the fourteenth amendment satisfies to that extent the requirement of [section 1983]."102 Since

96. See REPORT OF C. SchuRz, S. EXEC. Doc. No. 2, 39th Cong., 1st Sess. (1865).

97. Senator Edmunds, Chairman of the Senate Committee on the Judiciary, said of the Act of 1871:

The first section is one that I believe nobody objects to, as defining the rights secured by the Constitution of the United States when they are assailed by any State law or under color of any State law, and it is merely carrying out the principles of the civil rights bill [Act of 1866] which has since become part of the Constitution [fourteenth amendment]. Cong. GLOBE, 42d Cong., 1st Sess. 568 (1871).

98. See, e.g. Powell v. Pennsylvania, 127 U.S. 678, 684-85 (1888); Barbier v. Connolly, II 3 U.S. 27, 31 (1885); Butchers' Union Slaughter-house and Livestock Landing Co. v. Crescent City Livestock Landing \& Slaughter-house Co., 111 U.S. 746, 758 (1884) (Field, J., concurring).

99. Northwestern Fertilizing Co. v. Hyde Park, 18 F. Cas. 393 (No. 10,336) (C.C.N.D. III. 1873).

100. But see, 39 M1CH. L. REV., supra note 93, at 287.

101. 365 U.S. 167 (1961).

102. 365 U.S. at 171. See also id. at 206 (Opinion of Frankfurter, J.). 
the right to be free from unreasonable search and seizure is guaranteed from state infringement by the due process clause of the fourteenth amendment, the Court upheld the Monroes' claim against the police officer, under section 1983. Acknowledging that the purpose of the 1871 Act was to provide a remedy for the deprivation of rights secured by the fourteenth amendment including the right to due process, the Court made no distinction between property or personal rights. ${ }^{103}$ In pointing out that the decision ignored Holt and Hague, a commentator has concluded: "As a result of the Monroe decision, it seems unlikely that the district courts can avoid becoming forums for litigating every invasion of personal and property interest alleged to be a denial of due process."104

\section{Is Stone's Formulation Necessary?}

Justice Stone justified his formulation of section 1343(3) in order to reconcile section 1331 with section 1343(3). Was such a distinction really necessary to explain the coexistence of the two provisions, or can section 1343(3) be interpreted to provide federal jurisdiction against state deprivation of "any right, privilege, or immunity," regardless whether personal or proprietary? 1t must be remembered that Justice Stone was trying to preserve section 1343(3) jurisdiction from being swallowed by section.1331(1), not vice versa. ${ }^{105} \mathrm{He}$ did not argue that if section 1343(3) were interpreted to include property rights there would be no federal question jurisdiction left for the federal courts to exercise; rather he contended that in some types of federal cases Congress did not intend to apply the jurisdictional amount requirement. Obviously, Stone felt that personal rights such as freedom of speech or the right to vote, which could not be easily valued, were not intended by Congress to be subject to the amount requirement. Freedom of speech was the right at issue in Hague, and the defendants' argued that there were no jurisdiction under section 1343(3) even for the infringement of rights of personal liberty. Thus Stone's formulation at least insured that personal rights would not have to meet the jurisdictional amount

103. See 49 CALIF. L. REV., supra note 4, at 160.

104. Id. The scope of section 1983 is generally recognized to be coextensive with section 1343(3). Thus, an expansive interpretation of one necessarily affects the interpretation of the other. See note 86 supra and accompanying text.

105. 307 U.S. at 530, 531 . 
requirement. As the American Law Institute's study on jurisdiction stated:

[I]nsofar as it [Stone's formulation], dispenses with a monetary requirement where suit is to redress a right which cannot be valued in money, it is clearly desirable. Whether it is sound, however, to bar from federal court cases involving constitutional issues because a property right of less than $\$ 10,000$ is involved, is more doubtful..$^{00}$

If section 1343(3) were construed to protect both property and personal rights, section 1331 certainly would not be rendered superfluous. ${ }^{107}$ It must be remembered that section 1343(3) applies only to an alleged infringement of rights "under color of state law," and consequently in many federal question cases, such as suits against of ficials of the federal government, the jurisdictional amount is still required absent other statutory provisions. ${ }^{108}$ The purpose of section 1343(3)-to protect against unconstitutional state authority-is more limited in scope than genera] "federal question" jurisdiction. Further, it must be noted that the many statutes conferring jurisdiction without any monetary requirement lessen the impact of the section 1331 requirement on jurisdiction. ${ }^{109}$ Perhaps the fact that Congress has enacted the large number of statutes which except the majority of cases from any jurisdictional amount requirement lends support to the theory that state courts are not always satisfactory forums for the protection of federal rights, even when the amount in controversy is small. ${ }^{110}$ The American Law Institute's proposal to abolish the amount requirement altogether for federal question jurisdiction ${ }^{111}$ would effectively repeal section 1343(3), ${ }^{112}$ and arguably supports the contention that where a federal

106. Ali Study of the Division of Jurisdiction between State and Federal Courts, App. B, 202 (Tent. Draft No. 4, 1966).

107. See note 109 infra and accompanying text.

108. See. e.g., Fischler v. McCarthy, 117 F. Supp. 643 (S.D.N.Y.), aff d per curiant on other grounds, 218 F.2d 164 (2d Cir. 1954); Powers v. Gold, 124 F. Supp. 93 (D. Mass. 1953); .Wyoming v. Franke, 58 F. Supp. 890 (D. Wyo. 1945). See also Friedenthal, New Limitations on Federal Jurisdiction. II Stan. L. REv. 213, 217-18 (1959); Wechsler, Federal Jurisdietion and the Revision of the Judicial Code, 13 Law \& ConTEMP. Pros. 216, 225-26 (1948).

109. See D. CuRRIE, supra note 38, at 425 (partial listing of special statutes dispensing with jurisdictional amount); C. WRIGHT, supra note 36, at 93; ALI STUDY, supra note 106, at 78.

110. Friedenthal, supra note 110, at 217.

111. ALl STUDY, supra note 106, at 79. There being more justification for retaining the $\$ 10,000$ requirement in diversity cases where the parties are relying on state law than where the right relied on is federal, the ALl limited its proposal to abolishing the $\$ 10,000$ amount when the question is a federal one.

112. Id. at 78-81. Other commentators have also suggested abolishing the amount 
right is asserted, the federal government should provide a federal forum regardless of the nature of the right infringed.

\section{Conclusion}

At a time when there is increasing recognition that the federal judiciary should be the primary protector of federal rights, an exclusion of federal claims from federal courts because they involve property rights, albeit small, is no longer justified. As discussed above, the deprivation of property is no less important to many people than the so-called rights of personal liberty-indeed, for many individuals, the two are inextricably bound together. ${ }^{113}$ The distinction between personal and property rights is often difficult, if not impossible, to make as evidenced by the welfare and employment cases, and nothing in the legislative history indicates that Congress distinguished between the protection of these rights in.passing the Act of $18711^{114}$ Further, section 1331 would not be rendered superfluous-or any more so than it already is-by a construction of section 1343(3) which would include the protection of property rights. ${ }^{115}$ In Eisen v. Eastman, Judge Friendly recognized some of these criticisms of Stone's test and admitted doubts as to its continuing validity, but nevertheless upheld it "generously construed."116 Perhaps Judge Friendly was aware that one may "generously construe" any test to such an extent that it is no longer meaningful and then may be unceremoniously discarded.

requirement. See Cramton, Nonstatutory Review of Federal Administrative Action: The Need for Statutory Reform of Sovereign Immunity. Subject Matter Jurisdiction, and Parties Defendant, 68 Mich. L. REv. 389, 437-46 (1970).

113. See notes $78-81$ supra and accompanying text.

114. See notes $82-100$ supra and accompanying text.

115. See notes $106-09$ supra and accompanying text.

116. 421 F.2d at 566 . 
. 